\title{
PENGARUH MODEL PROBLEM BASED LEARNING TERHADAP HASIL BELAJAR SISWA PADA MATERI LISTRIK DINAMIS KELAS X DI SMA NEGERI 3 BINJAI
}

\author{
Ebet Elbita Tarigan dan Sehat Simatupang \\ Jurusan Fisika FMIPA Universitas Negeri Medan \\ elbita.tarigan@yahoo.com
}

\begin{abstract}
ABSTRAK
Penelitian ini bertujuan untuk mengetahui adanyapengaruhmodel Problem Based Learning terhadap hasil belajar siswa pada materi Listrik Dinamis kelas X Semester II SMA Negeri 3 Binjai T.P 2014/2015.Penelitian ini merupakan jenis penelitian quasi eksperimen. Populasi dalam penelitian ini adalah seluruh siswa kelas X Semester I SMA Negeri 3 Binjai yang berjumlah 303 siswa yang terdiri dari tujuh kelas. Sampel penelitian ini diambil dua kelas yaitu kelas $\mathrm{X}_{1}$ (sebagai kelas eksperimen) yang diberi perlakuan menggunakan model Problem Based Learning dan kelas $\mathrm{X}_{2}$ (sebagai kelas kontrol) yang diberi perlakuan menggunakan model Konvensional yang masing-masing berjumlah 37 orang yang ditentukan dengan cara ClusterRandom Sampling. Untuk memperoleh data yang diperlukan dalam penelitian ini digunakan tes pilihan berganda dengan jumlah 15 item dengan lima option jawaban yag sebelumnnya telah divalidasi.Data penelitian menunjukkan rata-rata pretes kelas eksperimen adalah 36,93dan pada kelas kontrol diperoleh rata-rata pretes 38,20 . Setelah diberikan perlakuan pada masing-masing kelas diperoleh rata-rata postes pada kelas eksperimen sebesar 71,18 dan pada kelas kontrol diperoleh rata-rata postes siswa 63,24. Hasil penelitian menunjukkan ada pengaruh menggunakan model Problem Based Learningterhadap hasil belajar siswa pada materi listrik dinamis kelas x semester II SMA Negeri 3 Binjai T.P 2014/2015.
\end{abstract}

Kata Kunci : Model Problem Based Learning, Hasil Belajar

\begin{abstract}
This study deals to determine the effect of the use of problem-based learning model for the learning outcomes of students in dynamic electrical material grade X Senior High School (SMA) 3 Binjai a.y. 2014/2015. Type of this research is quasi eksperimen. The research population is all students grade X Senior High School (SMA) 3 BinjaiT.P. 2014/2015 consist of seven class, in ways cluster random sampling, where class X-1(experiment class) and class X-2(control class). The instrument used is test result and student's activity observation sheet. Test of the learning outcomes in the form of multiple choice consist of 15 questions and also 5 answer choices that have been declared valid by the validator. The research of data showed that the average class pre-test experiment was 36,93 and in the control class gained an average of 38,20. After given the treatment to each class obtained an average grade post-testof the experiment class at 71,18 and in the control class gained an average of students' post-test 63,24 . The results showed that there are the effect of the use of problem-based learning model for the student learning outcomes on the material dynamic electrical grade X Senior High School (SMA) 3 Binjai a.y. 2014/2015.
\end{abstract}

Keywords: Problem Based Learning, Learning Outcomes. 


\section{PENDAHULUAN}

Kualitas

pendidikan di

Indonesia perlu ditingkatkan karena masih jauh tertinggal dibanding negara-negara lain . Di dunia internasional, kualitas pendidikan Indonesia berada di peringkat ke-64 dari 120 negara di seluruh dunia berdasarkan laporan tahunan UNESCO Education For All Global Monitoring Report 2012. Sedangkan berdasarkan Indeks Perkembangan Pendidikan (Education Development Index, EDI), Indonesia berada pada peringkat ke-69 dari

127negara pada2011.(http://www.prestasi-iief.org).

Banyaknya permasalahan yang dihadapi dalam dunia pendidikan saat ini, Salah satunya adalah masalah lemahnya proses pembelajaran. Dalam proses pembelajaran, anak kurang didorong untuk mengembangkan kemampuan berpikir. Proses pembelajaran di dalam kelas diarahkan kepada kemampuan anak untuk menghapal informasi. Otak anak dipaksa untuk mengingat dan menimbun berbagai informasi tanpa dituntut untuk memahami informasi yang diingatnya itu untuk menghubungkannya dengan kehidupan sehari-hari. (Sanjaya, 2008:1).

juga Proses pembelajaran dilapangan permasalahan dalam mengembangkan kemampuan berpikir siswa untuk memecahkan masalah. Pertama, cara guru mengajar masih banyak yang terlalu menekankan pada penguasaan sejumlah informasi/konsep belaka, artinya pembelajaran yang terjadi masih pembelajaran konvensional, hal ini menyebabkan banyak siswa merasa bahwa pelajaran fisika merupakan pelajaran yang sangat sulit karena selalu berkaitan dengan rumus. Siswa hanya menerima penjelasan yang disampaikan oleh guru, mencatatnya kemudian dihafal rumusrumusnya,ketika penyelesaian masalah pada soal, siswa membuka kembali lembaran sebelumnya untuk dicontohkan. Ketika salah satu simbol yang tampak pada soal yang diberikan guru berbeda dari sebelumnya, Maka siswa pun mulai kebingungan. kedua, jumlah siswa yang terlalu banyak dalam satu kelas sehingga membuat siswa cenderung untuk bermain-main dengan teman nya pada saat proses pembelajaran berlangsung. Ketiga, kurang lengkapnya fasilitas yang ada disekolah khususnya laboratorium sehingga tidak pernah dipergunakan secara maksimal untuk mendukung proses pembelajaran. Sehingga menumbuhkan rasa bosan bagi siswa dalam mengikuti proses pembelajaran di kelas dan menganggap bahwa fisika menjadi salah satu pelajaran yang sulit dipelajari.

Pernyataan di atas juga diperkuat dari hasil wawancara peneliti dengan salah satu guru fisika SMA Negeri 3 Binjai, yang mengatakan bahwa model yang digunakan dalam proses pembelajaran masih konvensional dan guru masih jarang melakukan metode eksperimen yang mampu membuat siswa berfikir kritis dan lebih mengerti akan kaitan konsepkonsep fisika dalam kehidupan seharihari. Kondisi tersebut dikarenakan kurang lengkapnya fasilititas yang ada dilaboratorium sehingga laboratorium disekolah tersebut jarang digunakan.

Salah satu alternatif yang dapat digunakan untuk mengatasi kesulitan tersebut adalah dengan menciptakan suasana pembelajaran yang langsung berhubungan dengan kehidupan seharihari. Model pembelajaran berdasarkan masalah adalah salah satu upaya solusinya, model pembelajaran ini dirancang dengan tujuan untuk membantu siswa mengembangkan kemampuan berfikir dan mengembangkan kemampuan dalam memecahkan masalah kehidupan sehari-hari (berbasis kontekstual), sehingga siswa lebih paham terhadap konsep fisika yang berkaitan dengan kehidupan sehari-hari. 
Upaya yang akan dilakukan peneliti dalam penelitian ini untuk memperbaiki kelemahan tersebut adalah: 1) menentukan masalah yang layak dijadikan masalah untuk dipecahkan saat proses pembelajaran berlangsung , 2) Membuat Lembar Kerja Siswa (LKS) sesuai dengan indikator pencapaian pembelajaran kognitif, 3) Memanfaatkan waktu sebaik mungkin sesuai yang direncanakan sehingga proses pembelajaran berjalan dengan baik, dan 4) mengorganisasikan kelompok sebaik mungkin agar anggotanya lebih sedikit dalam satu kelompok dan siswa dapat dikontrol dengan baik dalam proses pembelajaran.

Berdasarkan latar belakang masalah diatas, maka penulis terdorong untuk melakukan penelitian dengan judul " Pengaruh Model Problem Based LearningTerhadap Hasil Belajar Siswa Pada Materi Listrik Dinamis Kelas X Semester II SMA Negeri 3 Binjai T.P.2014/2015.

\section{METODE PENELITIAN}

Penelitian ini dilaksanakan di SMA Negeri 3 Binjai di kelas X. Waktu penelitian dilaksanakan bulan aprilmei tahun 2015.

Populasi penelitian ini adalah seluruh siswa kelas X semester II SMA Negeri3 Binjai yang berjumlah 7 kelas yaitu X-1 sampai X-7. Sampel dalam penelitian ini terdiri dari dua kelas yaitu kelas kontrol X-2 dan kelas eksperimen $\mathrm{X}-1$ yang di ambil dengan teknik simple random sampling sampel kelas di ambil sebanyak dua kelas, yaitu : kelas eksperimen dengan menggunakan model Problem Based Learning dan kelas kontrol menggunakan model pembelajaran konvensional.

$$
\text { Instrumen yang digunakan }
$$
adalahtes hasil belajar siswa dan lember observasiaktivitas siswa.Tes hasil belajarsiswa berjumlah lima belas (15) soal dalam bentuk pilihan bergandadengan lima pilihan (option) yang terlebih dahulu sudah di validasi isi oleh dua orang dosen dan satu guru bidang mata pelajaran fisika. Tes ini diberikansebanyak 2 kali yaitu pada saatpretes dan postes.Sedangkan lembar observasi digunakan untuk mengamati aktivitas belajar siswa selama pelaksanaan pembelajaran. Observasi dilakukan oleh observer yang berjumlah dua orang.

Penelitian ini melibatkan dua

kelas yang diberi perlakuan yangberbeda. Untuk mengetahui hasilbelajar fisika siswa dilakukandengan memberikan tes pada keduakelas sebelum dan sesudah diberikanperlakuan. Desain penelitiandapat dilihat pada Tabel 1 .

Tabel.1 Desain penelitian Two Group (Pretes dan Postes)

\begin{tabular}{|l|c|c|c|}
\hline \multicolumn{1}{|c|}{ Kelas } & Pre Tes & Perlakuan & Pos Tes \\
\hline Eksperimen & $\mathrm{T}_{1}$ & $\mathrm{X}$ & $\mathrm{T}_{2}$ \\
\hline Kontrol & $\mathrm{T}_{1}$ & $\mathrm{Y}$ & $\mathrm{T}_{2}$ \\
\hline
\end{tabular}

Keterangan:

$\mathrm{T}_{1}=$ Pemberian Tes awal (Pre Tes)

$\mathrm{T}_{2}=$ Pemberian Tes akhir (Pos Tes)

$\mathrm{X}=$ Perlakuan dengan model pembelajaran Inquiry Training

$\mathrm{Y}=$ Perlakuan dengan model pembelajaran konvensional

Dari hasil pretes yang diperoleh dilakukan uji prasyarat yaitu uji normalitas untuk mengetahui apakah data berdistribusi normal atau tidak. Kemudian dilakukan uji homogen untuk mengetahui apakah data bersifat homogen atau tidak. Setelah data berdistribusi normal dan juga homogen, maka dilakukan Uji $t$ dua pihak (uji kemampuan awal/ pretes)yang digunakan untuk mengetahui kesamaan kemampuan awal siswa pada kedua kelompok sampel. Selanjutnya apabila kedua kelas sampel diketahui mempunyai kemampuan awal yang sama maka kedua sampel diberikan perlakuan yang berbeda. Kelas eksperimen diberikan perlakuan dengan model 
Problem Based Learning dan kelas kontrol diberikan perlakuan dengan menggunakan model pembelajaran konvensional. Setelah diberikan perlakuan maka selanjutnya adalah kedua kelas diberikan postes. Untuk mengolah data pada postes sama seperti pada pretes dilakukan uji prasyarat yaitu uji normalitas dan uji homogen. Setelah data berdistribusi normal dan juga homogen maka dilakukaan uji $t$ satu pihak (uji kemampua akhir/ potes) yang digunakan untuk mengetahui apakah hasil belajar siswa dengan menerapkan modelProblem Based Learning lebih tinggi dibandingkan dengan model pembelajaran konvensional pada materi listrik dinamis.

\section{HASIL DAN PEMBAHASAN Hasil Penelitian}

Pada awal penelitian, kedua kelas diberikan tes uji kemampuan awal (pretes) yang bertujuan untuk mengetahui apakah kemampuan awal siswa pada kedua kelas sama atau tidak. Berdasarkan data hasil penelitian diperoleh nilai rata-rata pretes siswa pada kelas eksperimen sebesar36,93 dengan standar deviasi 12,82. Sedangkan di kelas kontrol diperoleh nilai rata-rata pretes 38,20 dengan standar deviasi 12,13.

Tabel 2. Data Nilai Pretes Kelas

Eksperimen dan Kelas Kontrol

\begin{tabular}{|c|c|c|c|c|c|}
\hline \multicolumn{3}{|c|}{ Kelas Eksperimen } & \multicolumn{3}{|c|}{ Kelas Kontrol } \\
\hline Nilai & $\begin{array}{c}\text { Freku } \\
\text { ensi }\end{array}$ & $\begin{array}{c}\text { Rata- } \\
\text { rata }\end{array}$ & Nilai & $\begin{array}{c}\text { Freku } \\
\text { ensi }\end{array}$ & $\begin{array}{c}\text { Rata- } \\
\text { rata }\end{array}$ \\
\hline $13-18$ & 3 & \multirow{9}{*}{36,93} & $13-18$ & 2 & \multirow{9}{*}{38,20} \\
\hline $19-24$ & 3 & & $19-24$ & 3 & \\
\hline $25-30$ & 5 & & $25-30$ & 4 & \\
\hline $31-36$ & 6 & & $31-36$ & 6 & \\
\hline $37-42$ & 8 & & $37-42$ & 9 & \\
\hline $43-48$ & 6 & & $43-48$ & 7 & \\
\hline $49-54$ & 4 & & $49-54$ & 4 & \\
\hline $55-60$ & 2 & & $55-60$ & 2 & \\
\hline$\sum$ & 37 & & $\sum$ & 37 & \\
\hline
\end{tabular}

Sedangkan setelah diberikan perlakuan yang berbeda dimana pada kelas eksperimen dengan model Problem Based Learning dan pada kelas kontrol dengan pembelajaran Konvensional, diperoleh bahwa ratarata postes kelas eksperimen sebesar 76,98 dan rata-rata postes kelas kontrol sebesar 71,14.Untuk selengkapnya, hasil pretes siswa digambarkan pada tabel 3 berikut ini.

Tabel 3. Data Nilai Postes Kelas

Eksperimen dan Kelas Kontrol

\begin{tabular}{|c|c|c|c|c|c|}
\hline \multicolumn{3}{|c|}{ Kelas Eksperimen } & \multicolumn{3}{|c|}{ Kelas Kontrol } \\
\hline Nilai & $\begin{array}{l}\text { Frek } \\
\text { uensi }\end{array}$ & $\begin{array}{c}\text { Rata- } \\
\text { rata }\end{array}$ & Nilai & $\begin{array}{l}\text { Frek } \\
\text { uensi } \\
\end{array}$ & $\begin{array}{c}\text { Rata- } \\
\text { rata }\end{array}$ \\
\hline $46-51$ & 2 & \multirow{8}{*}{71,18} & $40-45$ & 2 & \multirow{8}{*}{63,24} \\
\hline $52-57$ & 2 & & $46-51$ & 3 & \\
\hline 58-63 & 3 & & 52-57 & 4 & \\
\hline 64-69 & 8 & & $58-63$ & 9 & \\
\hline $70-75$ & 10 & & 64-69 & 8 & \\
\hline 76-81 & 8 & & $70-75$ & 7 & \\
\hline $82-87$ & 4 & & $76-81$ & 4 & \\
\hline$\sum$ & 42 & & $\sum$ & 42 & \\
\hline
\end{tabular}

Dalam penelitian ini, perkembangan aktivitas belajar siswa pada kelas eksperimen diamati selama tiga kali pertemuan dan hasil perkembangan aktivitas siswa dapat dilihat pada gambar 1 di bawah ini.

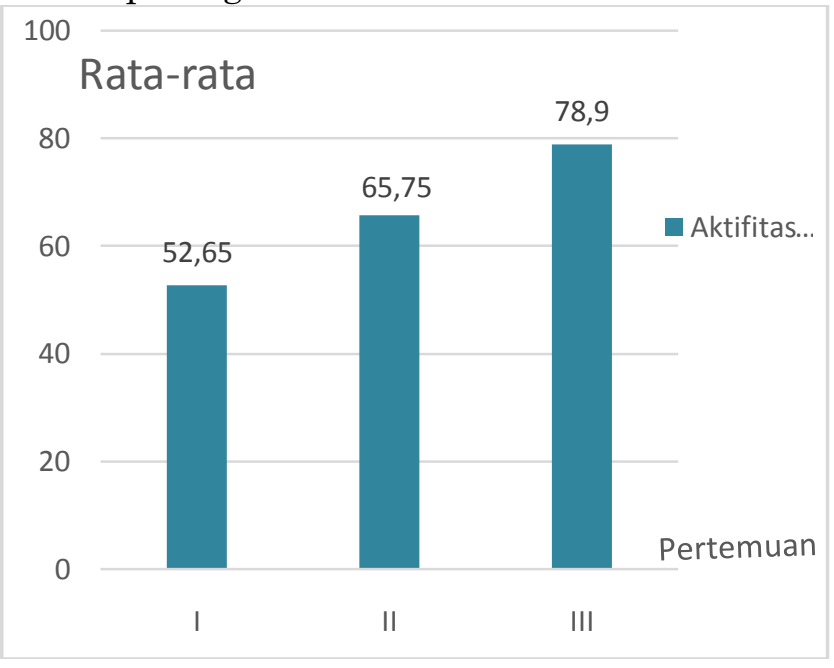

Gambar 1. Diagram Batang Perkembangan Aktivitas Siswa Kelas Eksperimen 
Dari gambar 1 di atas dapat kita ketahui bahwa selama tiga kali pertemuan di kelas eksperimen siswa mengalami peningkatan aktivitas siswa yang cukup baik.

\section{PEMBAHASAN}

Hasil penelitian menunjukkan bahwa ada pengaruh model Problem Based Learning terhadap hasil belajar fisika pada materi Listrik Dinamis di SMA Negeri 3 Binjai. Hal ini dapat dilihat melalui data hasil penelitian yang diperoleh, dimana nilai rata-rata postest pada kelas eksperimen adalah 71,18 sedangkan nilai rata-rata postest pada kelas kontrol adalah 63,24, maka peningkatan hasil belajar sebesar 7,94.

Besarnya peningkatan hasil belajar di kelas eksperimen pada saat proses belajar denganmenggunakan model problem based learningmenuntut siswa belajar secara langsung dengan pemberian pengalaman secara langsung yang berkaitan dengan kehidupan sehari-hari sehingga siswa menemukan dan mampu memecahkan masalah. Model Problem Based Learning mampu menumbuhkan motivasi belajar siswa, dapat memberikan kesempatan pada siswa bereksplorasi mengumpulkan dan menganalisis data untuk memecahkan masalah, sehingga siswa mampu untuk berpikir kritis. Sesuai dengan pernyataan Arends (2008), "PBL tidak dirancang untuk membantu guru menyampaikan informasi dengan jumlah besar kepada siswa,tapi dirancang terutama untuk membantu siswa mengembangkan keterampilan berpikir,khususnya keterampilan berpikir tingkat tinggi (higher-level thingking skill).

Hal ini juga sejalan dengan penelitian terdahulu seperti yang di teliti oleh Lilatul Husnah (2012), menyatakan bahwa hasil belajar siswa di kelas yang diberikan pembelajaran berbasis masalah hasil postesnya 68,14 sedangkan hasil belajar siswa di kelas kontrol hasil postesnya62,86.
Selanjutnya,Mariana Lumbantobing (2013), menyatakan ada pengaruh model pembelajaran berdasarkan masalah terhadap hasil belajar siswa dapat dilihat dari hasil postesnya 70,47 (untuk pembelajaran berdasarkan masalah) dan 63,44 (untuk model konvensional).

Demikian juga aktivitas siswa pada kelas eksperimen mengalami peningkatan yaitu pada pertemuan I rata-rata aktivitas siswa kelas eksperimen 52,65 , pada pertemuan II rata-rata adalah 65,75 sedangkan pada pertemuan III meningkat menjadi 79,80. Jadi dari keseluruhan diperoleh nilai rata-rata aktivitas siswa selama pembelajaran dengan model pembelajaran Problem Based Learning berbantu adalah 66,08 dan digolongkan aktif. Pada kelas kontrol aktivitas siswa juga mengalami peningkatan yaitu pada pertemuan I rata-rata 43,08 , pada pertemuan II rata-rata adalah 51,61 sedangkan pada pertemuan III meningkat menjadi 60,36. Jadi nilai rata-rata aktivitas siswa selama pembelajaran dengan model pembelajaran Konvensional adalah 51,68 dan digolongkan cukup aktif.

Model problem based learning dapat memberikan kesempatan pada siswa bereksplorasi mengumpulkan dan menganalisis data untuk memecahkan masalah, sehingga siswa mampu untuk berpikir kritis, analitis, sistematis, dan logis dalam menemukan alternatif pemecahan masalah. Siswa dalam hal ini aktif dan antusias untuk bekerja sama dengan teman satu kelompok dalam menyelesaikan masalah yang telah diberikan oleh peneliti. Siswa juga tertarik dan aktif saat berdiskusi dan mengeluarkan pendapat yang berbeda saat diadakan diskusi antar kelompok.

Pelaksanaan pembelajaran ini terfokus pada lima komponen utama model Problem Based Learning, yaitu : 1) Orientasi siswa pada masalah; penyampaian materi ajar dilengkapi dengan bantuan peta konsep tentang 
materi listrik dinamis guna meningkatkan daya ingat siswa terhadap materi yang diajarkan, 2) Mengorganisasikan siswa untuk belajar; setiap siswa diajak untuk mengelompokkan diri ke teman lainnya untuk dapat menyelesaikan masalah bersama, 3) Membantu menyelidiki secara mandiri atau kelompok; siswa berusaha untuk mencari penyelesaian masalah dan peneliti membimbing siswa serta membantu siswa yang mendapatkan kesulitan untuk menyesaikan masalah yang diberikan pada setiap kelompok, 4) Mengembangkan dan menyajikan hasil kerja; setiap kelompok yang sudah mampu memecahkan masalah harus dipresentasikan untuk melatih siswa berbicara di depan kelas, kemudian kelompok yang lain diberikan kesempatan memberikan pendapat atau masukan. 5) Menganalisa dan mengevaluasi hasil pemecahan; siswa mampu menganalisa setiap penjelasan masalah yang dikemukan oleh teman kelompoknya dan peneliti membantu siswa dalam mengkaji ulang pemecahan masalah sesuai dengan tujuan pembelajaran dan memberikan penguatan pada pemecahan masalah tersebut dan pada tahap ini peneliti membuat tes evaluasi untuk mengetahui pemahaman siswa.

Walaupun model Problem Based Learning telah membuat hasil belajar yang lebih tinggi dibandingkan dengan model pembelajaran konvensional, tetapi peneliti juga mengakui bahwa hasil belajar siswa tidak begitu besar hanya memiliki selisih nilai 7,94 point. Ini disebabkan peneliti mendapatkan kendala-kendala dalam melakukan penelitian, disamping peneliti baru pertama kalinya melakukan penelitian. Sehingga masih banyak memiliki kekurangan-kekurangan dalam melaksanakan penelitian.

Adapun yang menjadi kendalakendala dalam penelitian adalah1) Ketika menentukan masalah apa yang layak dijadikan masalah yang akan dipecahkan saat proses pembelajaran berlangsung, adapun syarat menentukan masalah harus memiliki lima kriteria yaitumasalah autentik, menciptakan misteri, sesuai tingkat intelektual siswa, masalah yang cukup luas, dan harus mendapatkan manfaat dari usaha kelompok. 2)Pembagian kelompok siswa dalam kelompok belajar membutuhkan waktu yang lama ditambah dengan adanya siswa yang tidak memiliki hubungan yang baik dengan teman kelompoknya, merasa tidak senang dengan teman kelompoknya, minta ganti teman kelompok,sehingga peneliti harus lebih tegas dan berusaha mendamaikan anggota kelompok yang tidak harmonis terlebih dahulu. 3) Peneliti belum maksimal dalam mengelola waktu disebabkan karena peneliti belum berpengalaman mengajar menggunakan model Problem Based Learning sehingga semua sintaks kurang efektif saat pelaksanaan proses pembelajaran.

\section{KESIMPULAN DAN SARAN Kesimpulan}

Berdasarkan hasil analisis data, dapat disimpulkan bahwa ada pengaruh penggunaan model Problem Based Learning terhadap hasil belajar siswa pada materi listrik dinamis kelas $\mathrm{X}$.

\section{Saran}

Berdasarkan hasil pembahasan penelitian yang dikemukakan, maka sebagai tindak lanjut dari penelitian ini,peneliti mempunyai saran-saran sebagai berikut:

1. Bagi peneliti selanjutnyayang ingin meneliti menggunakan model Problem Based Learning, hendaknya lebih memahami bagaimana mengambil masalah seperti apa yang layak dijadikan masalah dalam pembelajaranuntuk dipecahkan oleh siswa yang akan diberi perlakuan.

2. Bagi peneliti selanjutnya agar pembentukan kelompok pada model 
pembelajaran Problem Based Learning dapat dilakukan sebelum kegiatan

pembelajaran dilaksanakan. Denga $\mathrm{n}$ demikian, dalam kegiatan pembelajaran tidak ada waktu yang terbuang untuk pembentukan kelompok dan penataan ruang kelas.

3. Bagi peneliti selanjutnya yang ingin meneliti menggunakan model Problem Based Learning, disarankan untuk memperhatikan efisiensi waktu sehingga semua sintaks efektif saat pelaksanaan proses pembelajaran.

\section{DAFTAR PUSTAKA}

Arends,R. 2008. Learning To Teach. Yogyakarta: Pustaka Pelajar

Sanjaya, W. 2008. Strategi Pembelajaran Berorientasi Standar Proses Pendidik. Bandung: Kencana Prenada Media Group

Lubis, L. H. 2012. Pengaruh model Pembelajaran Berdasarkan Masalah Terhadap Hasil Belajar Siswa pada Materi Pokok Listrik Dinamis Kelas $X$ semester $2 d i$ SMA N 1 Labuhan Deli T.A. 2011/2012, Skripsi FMIPA Unimed, Medan: FMIPA Unimed

Lumbantobing, M. 2013. Pengaruh Model Pembelajaran Berdasarkan Masalah Terhadap Prestasi Beajar siswa pada materi pokok Gerak Lurus Kelas X semester I SMA Negeri 11 Medan T.A.2013/2014. Skripsi FMIPA Unimed. Medan: FMIPA Unimed (http://www.prestasiiief.org/index. $\mathrm{php} / \mathrm{id} /$ feature/68-kilas-balikdunia-pendidikan-di-indonesia,). 